\title{
METAL REDUCTION FROM LANDFILL LEACHATE BY USING BLAST FURNACE SLAG AND PINE BARK - DISCUSSION ABOUT THE PARAMETERS SIGNIFICANT FOR METAL REMOVAL
}

\author{
Emma Nehrenheim \\ Mälardalen University, Sweden
}

\begin{abstract}
In Sweden there are many old landfills of which the content is more or less unknown. The leachates from these are of varying quality, mirroring the waste deposited in the landfills. Metals commonly occurring in leachates are i.e. zink $(\mathrm{Zn})$, lead $(\mathrm{Pb})$, cupper $(\mathrm{Cu})$ and nickel (Ni). $\mathrm{Ni}$ is of particular interest due to the un-predictable mobility of the metal. For small, weak leachates a passive low-cost treatment system can be suitable. Reactive filter technology is one alternative and by using by-products from national and global industries the environmental benefit could be further increased. Pine bark (from pulp and paper industry) and blast furnace slag (from steel manufacturing) are examples of such materials. Designing filters for removal of metals from leachate includes taking a series of parameters into account. At the landfill site in Eskilstuna, Sweden, a facility was designed as a pilot study. Four columns were filled with filter material. The materials were sand, amorphous and crystalline blast furnace slag and pine bark. The aim was to investigate parameters significant for metal uptake from landfill leachate. A screening of the metals, physio-chemical parameters and some organic pollutants was conducted for a period of five months. A part from this, a batch experiment was conducted. Contact time, initial concentration, other leachate components and $\mathrm{pH}$ are examples of parameters that have a significant influence on the metal removing capacity of a filter.
\end{abstract}

\section{KEYWORDS}

Sorption; Metals; On-site treatment; Leachate

\section{INTRODUCTION}

The presence of metals in natural water ecosystems is normally poor. Therefore releasing even small amounts of metals with effluents can rise up the heavy metal level to become environmentally impacting. Not only the concentration of metals in water eco systems, is important but also the character of the water. Among other factors, the toxicity of metals is often negatively correlated to the degree of hardness of the water. In Sweden most of the water eco systems are soft and sensitive to heavy metals. [1] 
Landfill leachate originates from surface or ground water percolating through refuses [2]. Dependent upon the content of the landfill small or large amounts of metals are released with the leachate to the water phase creating a possibly hazardous effluent. For severely contaminated waters advanced systems must be designed. These cost and operational demanding systems are however sensitive to dilution by weak leachate streams from around the landfill. Still, also these weak leachate streams requires treatment but the energy and resource cost must correspond to the environmental benefit in treating the leachate. Passive treatment systems have been under research during the past years aiming to find an environmentally friendly method to treat small streams on-site. Reactive filter technology is a method that has been studied for all kinds of contaminated waters, e.g. phosphorus [3], uranium [4], phenol and phentachlorphenol [5] as well as heavy metals [6-9]. The reactivity in the filter technology refers to sorption to the particle surfaces. Sorption is a wide term that is represented by a continuous process ranging from adsorption to precipitation [3]. Adsorption is a slower process with low solubility whereas precipitation is a fast reaction with high solubility.

$\mathrm{Ni}$ and $\mathrm{Zn}$ are both adsorbing metals in soil [10]. The similarity in sorption capacity to particles makes them interesting to investigate in corresponding sorption experiments. The mobility of the metals is agreed by researchers to be strongly $\mathrm{pH}$-dependent $[6,10]$ and the mobility is the highest at low pH. Both $\mathrm{Zn}$ and $\mathrm{Ni}$ form surface complexes but $\mathrm{Ni}$ can also be precipitated as mixed $\mathrm{Ni} / \mathrm{Al}$ hydroxides. $\mathrm{Zn}$ can form poorly soluble sulphides which $\mathrm{Ni}$ can not and hence the Ni sorption/mobility is poorly affected by the presence of sulphide. [10] The time of which each solution element was in contact with the filter particles, was studied by $[11,12]$.

The aim of the present paper is to glance at the research performed concerning heavy metals and reactive filter materials with special focus on parameters influencing the sorption process. A part from this aim the paper also gives some results from an on-site research project performed during 2005. The objective in the project was among others to compare sorption capacity in laboratory with field condition to be able to start the process of finding key parameters in the sorption process.

\section{MATERIALS AND METHODS}

\subsection{Landfill leachate}

The landfill chosen for the study was Lilla Nyby, Eskilstuna, Sweden. The main leachate stream on the site contains large amounts of ammonium. The treatment of this stream is very accurate and the high technology ammonium stripping plant is most effective at high ammonium concentrations. Around the landfill however, there are a series of small weak streams that requires treatment, primarily due to the high concentration of heavy metals. Adding these streams to the main stream would cause dilution and un-efficiency in the ammonium stripping.

One of the weak streams, in the western part of the landfill, has been in focus in the present study. The 50 year old landfill from where it origins contaminates the groundwater flowing through the small landfill. The total production of leachate that requires treatment at this part of the site is estimated to $2000 \mathrm{~m}^{3} /$ year. 
The study began with a series of five samplings where physio-chemical parameters were analysed in accredited laboratory. The aim of the screening was to characterize the leachate before choosing interesting filter materials. The screening was described further by Nehrenheim et al [12].

\subsection{Filter materials}

The materials tested are pine bark and two blast furnace slag spieces, amorphous and crystalline. The slags differ by the cooling procedure when coming out from the furnace. The slag can either be air-cooled slowly on solid ground which gives the slag some time to crystallise, or be rapidly cooled in water basins which gives an amorphous structure to it. The pine bark used is a commercial product $\left(\mathrm{Zugol}^{\mathrm{TM}}\right)$ developed for uptake of oils, blood, urine or other spilled liquids [13]. Bark is a by product in many Swedish manufacturing industries such as pulp and paper and woods. Particle size distribution is $Ø 2-10 \mathrm{~mm}$ and amorphous slag $<$ crystalline slag < pine bark. The materials have been further described by reference [12].

\subsection{Batch and column experiments}

The present study focuses mainly on the behaviour and uptake of $\mathrm{Ni}, \mathrm{Cu}$ and $\mathrm{Zn}$ from leachate but is only a part of a large investigation aiming to treat weak leachate.

The on site column set up was run for four month examining three different flow rates; $1,0.5$ and $0.14 \mathrm{l} / \mathrm{min}$ using a volumetric pump. Four columns $(\varnothing 0.15 \mathrm{~m}$, height $0.6 \mathrm{~m})$ were filled with; inert sand (1), pine bark (2), amorphous slag (3) and crystalline slag (4). The set up has been illustrated in Figure 1. Sampling was conducted two to three times a week (variances dependent upon practical reasons) during four months. Double samples were taken from the inlet of the volumetric pump and outlet of each column. All samples were transported to laboratory where they were filtered and preserved with $2 \mathrm{M}$ sulphuric acid. Once a week extra double samples were taken for analysis of $\mathrm{pH}$, electric conductivity and content of suspended solids (SS).

As a complementary to the on-site study batch experiments were carried out to determine the maximum uptake of $\mathrm{Ni}$ under condition where no disturbances such as variation in climate or substances influencing the adsorption were present. The laboratory batch experiments were conducted using solutions contaminated with five metals $\left(\mathrm{Zn}\left(\mathrm{Zn}\left(\mathrm{NO}_{3}\right)_{2} 6 \mathrm{H}_{2} \mathrm{O}\right), \mathrm{Pb}\left(\mathrm{N}_{2} \mathrm{O}_{6} \mathrm{~Pb}\right)\right.$, $\mathrm{Cu}\left(\mathrm{Cu}\left(\mathrm{NO}_{3}\right)_{2} 3 \mathrm{H}_{2} \mathrm{O}\right), \mathrm{Cr}\left(\mathrm{Cr}\left(\mathrm{NO}_{3}\right)_{2} 9 \mathrm{H}_{2} \mathrm{O}\right)$ and $\left.\mathrm{Ni}\left(\mathrm{N}_{2} \mathrm{NiO}_{6} 6 \mathrm{H}_{2} \mathrm{O}\right)\right)$ in three different concentrations $(0.2 \mathrm{mg} / \mathrm{l}, 2 \mathrm{mg} / \mathrm{l}$ and $20 \mathrm{mg} / \mathrm{l}) .10 \mathrm{~g}$ of slag or $5 \mathrm{~g}$ of pine bark were shaken with $50 \mathrm{ml}$ of each solution for 1, 10,100 and 1000 seconds respectively. The set up resulted in 36 different mixtures which were repeated for 3 replicates resulting in totally 108 batches.

All samples, both from the column study and batch experiments, were then analyzed for the metals by means of atomic absorption spectrometry (AAS) with AAS Vario 6 instrument, using flame technique or graphic tube in accordance to Swedish Standard [14]. The lower detection limits for the flame were for $\mathrm{Zn} ; 0.0014 \mathrm{mg} / \mathrm{l}, \mathrm{Pb} ; 0.013 \mathrm{mg} / \mathrm{l}, \mathrm{Cu} ; 0.003 \mathrm{mg} / \mathrm{l}$ and $\mathrm{Cr} ; 0.0054 \mathrm{mg} / \mathrm{l}$, respectively. 


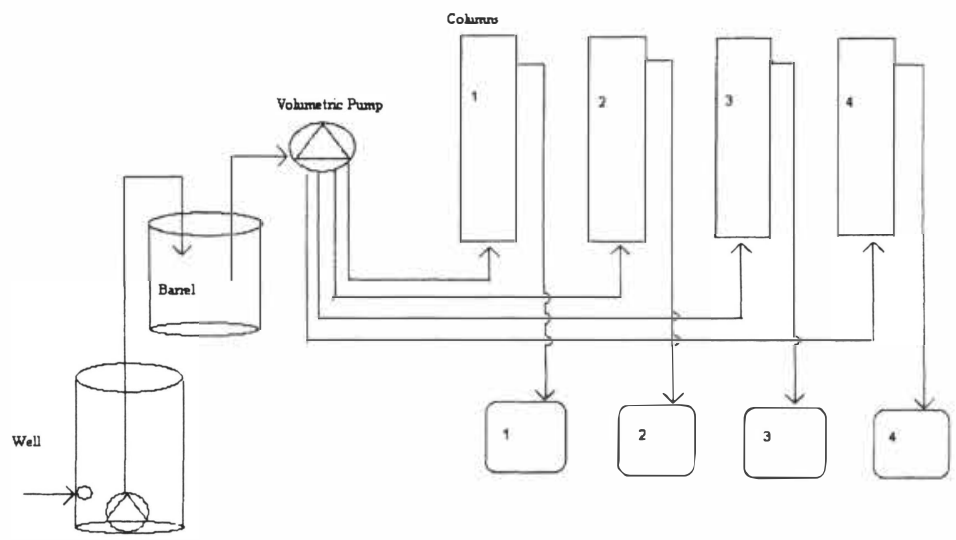

Figure 1. Set up of columns at Lilla Nyby landfill [15]

\section{RESULTS AND DISCUSSION}

\subsection{Leachate screening}

From the screening $\mathrm{Cu}, \mathrm{Zn}$ and $\mathrm{Ni}$ was found to be two of the heavy metals present in significant levels compared to a Swedish examination of 14 landfills [12, 16]. It was also found that the character of the leachate varied from one sampling point to another but that $\mathrm{pH}$ was stable around 7.3 (standard deviation, $\mathrm{SDt}=0.2$ ) and the electric conductivity $1162 \mathrm{mS} / \mathrm{m}$ $(\mathrm{SDt}=310 \mathrm{mS} / \mathrm{m})$.

\subsection{Column experiment}

The mean uptake to the materials in the column experiment on the landfill site has been illustrated in Figure 2. Pine bark proved to be more stable than the slags when it comes to reducing $\mathrm{Cu}, \mathrm{Zn}$ and $\mathrm{Ni}$. It was found that the net uptake to the slags was negative, even though the uptake was close to $80 \%$ at high metal concentrations, due to the desorption that occurred at concentration drops. For slag, especially amorphous slag, the net desorption rate appeared to increase as the contact time increased. The uptake of $\mathrm{Ni}$ throughout the period was never higher than $25 \%$ but one should remember that the leachate $\mathrm{Ni}$ concentration was never higher than $8 \mu \mathrm{g} / \mathrm{l}$. The uptake to pine bark was the highest during the last period when the inlet flow was decreased to $0.14 \mathrm{l} / \mathrm{min}$. The highest inlet flow rate of $1 \mathrm{l} / \mathrm{min}$ resulted in desorption (flushing) for all materials and metals except for $\mathrm{Ni}$ uptake to pine bark. The uptake, however, of $\mathrm{Ni}$ to pine bark was very low. When the inlet flow rate was decreased the first time (to $0.51 / \mathrm{min}$ ) the net uptake of $\mathrm{Zn}$ and $\mathrm{Cu}$ was still negative for amorphous slag whilst the Ni net uptake was higher. Perhaps the lack of competition of sorption sites favoured the $\mathrm{Ni}$ uptake. One should remember though, that the uptake was still below $15 \%$. The variations between inlet concentration and rate of uptake limit the possibility of finding significant differences between different materials and inlet flow rate. This also indicates that there are unknown processes in the reactive filters that need further investigation.

Previous research [6] has found that $\mathrm{pH}$ significantly increases solution $\mathrm{pH}$ in the sorption process by using slag. The present study shows that there was a mean $\mathrm{pH}$ increase for 

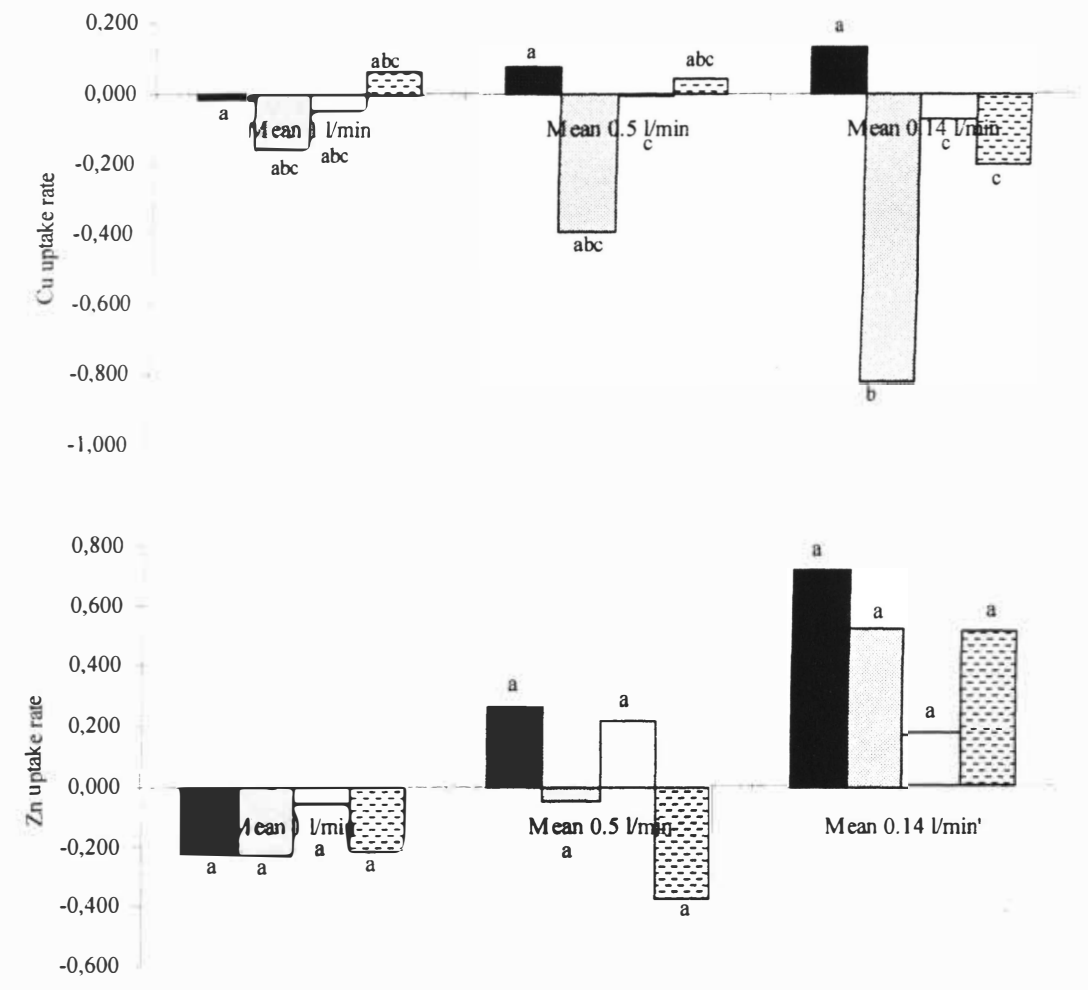

0,150

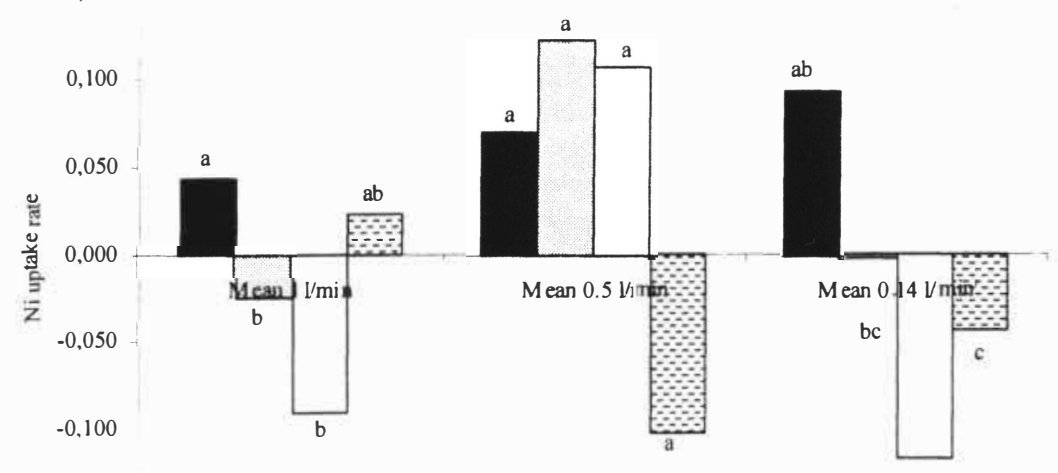

$-0,150$

a Pine bark $\square$ Amorphous slag $\square$ Crystalline slag $\square$ sand

Figure 2. Mean uptake rate to pine bark (black staple), amorphous slag (shaded staple) and crystalline slag (white staple) as well as the reference column (sand) in the column experiment at Lilla Nyby Landfill. Letters illustrate significance $(p=0.1)$ using student $t$-test. 
Kalmar ECO-TECH '05 and

The Second Baltic Symposium on Environmental Chemistry

KALMAR, SWEDEN, November 28-30, 2005
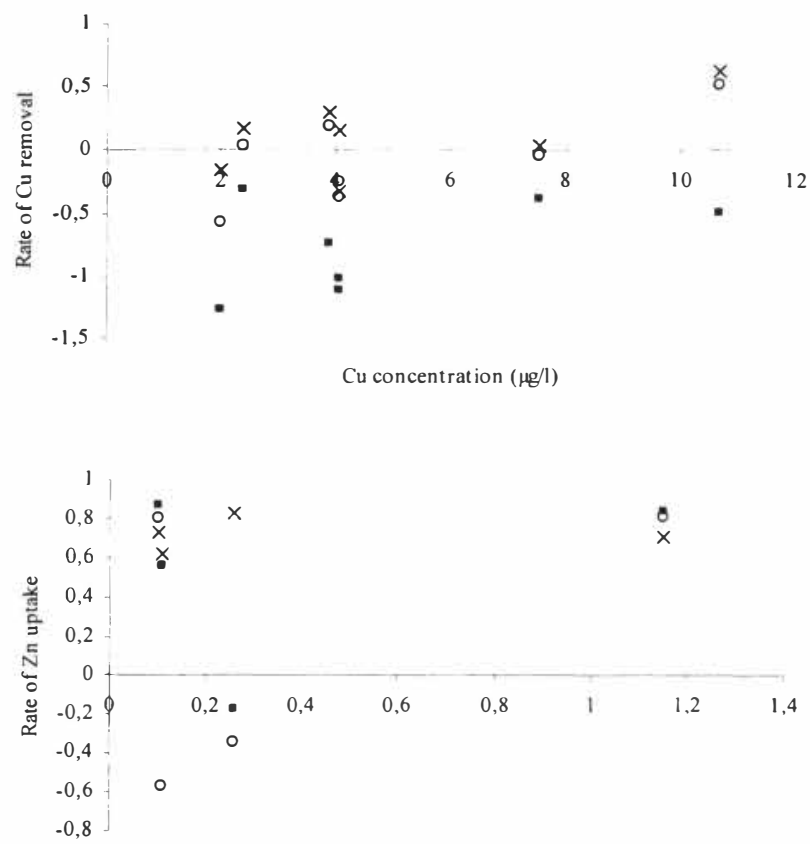

$\mathrm{Zn}$ concentration $(\mathrm{mg} /)$

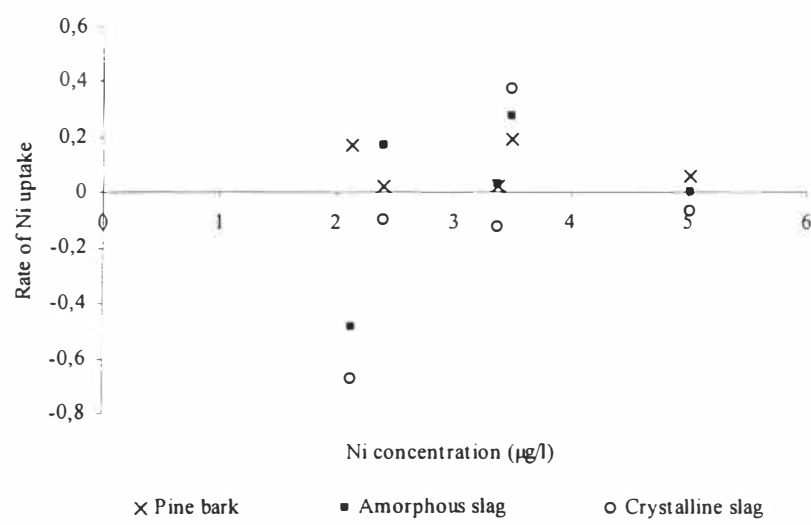

Figure 3. Metal uptake rate of $\mathrm{Cu}, \mathrm{Zn}$ and Ni to filter materials in the column study for the last period of the project (flow rate; $0.14 \mathrm{l} / \mathrm{min}$ ) at Lilla Nyby landfill, plotted against the inlet metal concentration of each metal. 
crystalline slag was $0.118(\mathrm{SD}=0.19)$ units and for amorphous slag $0.15(\mathrm{SD}=0.09)$ units. The mean $\mathrm{pH}$ change in the pine bark and the reference (inert sand) column was $0.112(\mathrm{SD}=0.09)$ and $0.11(\mathrm{SD}=0.08)$ units, respectively. The $\mathrm{pH}$ appears to be affected by the sorption process but not to a high extent.

It can not be guaranteed that the inlet and outlet concentrations of the metals are exactly corresponding since there can be variations in the flow rate inside the columns. The concentration in the leachate varied a lot during the research period. It can probably be assumed though, that the difference in inlet metal concentration during the few minutes of sampling is small enough to have poor significance for the research result.

Initial concentration of metals has been concluded by researchers to be significant for the metal uptake in laboratory batch experiments $[17,11]$. In agreement to this the data from the present study showed the trend of metal uptake being somewhat related to concentration. The rate of $\mathrm{Cu}, \mathrm{Zn}$ and $\mathrm{Ni}$ removal from the last period of the on-site column study (inlet flow rate $0.141 / \mathrm{min}$ ) has in Figure 3 been plotted against the inlet concentration of corresponding metal. $\mathrm{Cu}$ uptake (top figure) showed a proportional trend against the inlet concentration. In the amorphous slag column metals were desorbed to the leachate instead of adsorbed. Desorption appeared however to decrease as the inlet concentration increased. Much of the Cu uptake to the crystalline slag showed the same results but as concentration increased over $8 \mu \mathrm{g} / \mathrm{l}$ there was a $\mathrm{Cu}$ uptake as was the same for pine bark. Pine bark also managed to take up metals at low concentrations of $\mathrm{Cu}$ but only in rather small amounts.

$\mathrm{Zn}$ uptake to all the materials appeared according to the results presented in Figure 3 to have an uptake rate close to $90 \%$. At low concentrations a couple of exceptions were found for the slags which desorbed $\mathrm{Zn}$.

As shown in Figure 3 there did not seem to be an obvious relationship between inlet concentration and $\mathrm{Ni}$ uptake to pine bark in the column experiment on-site. For the lowest flow rate pine bark had a significant uptake of $\mathrm{Ni}$.

\subsection{Laboratory experiment}

Special focus has been addressed to the uptake rate of $\mathrm{Ni}$ in the presentation of the laboratory results. The both slag materials showed unstable sorption behaviour and released metal solutes as the concentration dropped. Pine bark on the other hand managed to hold the $\mathrm{Ni}$ throughout the period with exception of two occasions when there was a $20 \%$ release. The longer the contact time between the pine bark and the metal solution the better reduction was achieved. It was found in previous research [18] that maximum percentage removal of $\mathrm{Ni}$ from solution using sawdust is reached after $1 \mathrm{~h}$. From the laboratory (see Figure 4) results the sorption capacity of the three materials varied significantly. Amorphous slag (A) sorbed the highest percentage rate of $\mathrm{Ni}$ (at inlet concentration $2 \mathrm{mg} / \mathrm{l}$ ). 
A

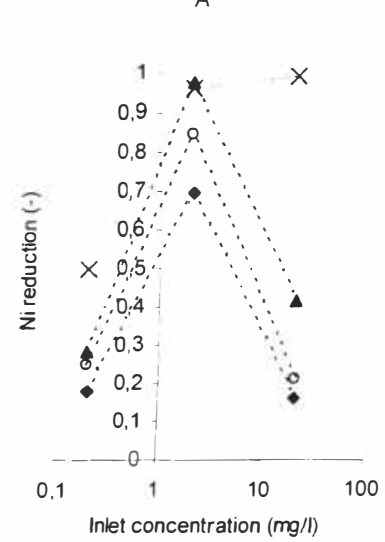

B

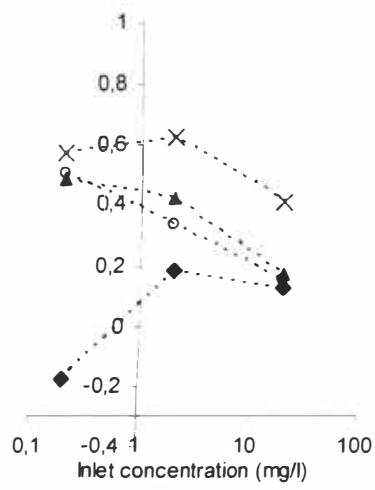

C

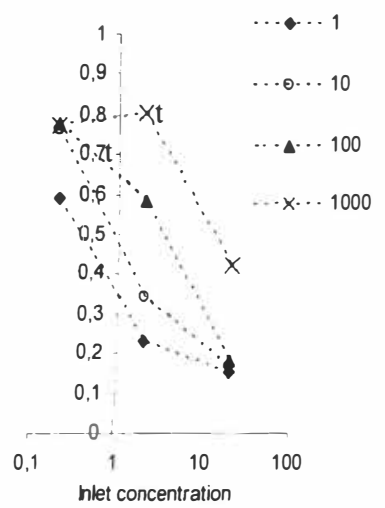

Figure 4. Laboratory batch results for Ni uptake to amorphous slag (A) crystalline slag (B) and pine bark $(C) \mathrm{t}$

At lower concentrations the uptake was lower as well as for higher concentrations. Sorption equilibrium is a slow process which implies that a longer contact time could have resulted in a higher rate of metal reduction. The corresponding flow however for the columns might have been too low to be effective, depending on the definition of contact time in a percolating flow. Crystalline slag (B), however was a percentage more efficient sorbent at lower concentrations than at higher except for the shortest contact time of 1 second were the material released $\mathrm{Ni}$ at the low concentration $(0.2 \mathrm{mg} / \mathrm{l})$. The latter being in agreement with the results from the column studies with even lower concentration. The percentage uptakes of Ni to pine bark (C) decreased almost logarithmically with increasing inlet concentration at all contact times. Even at contact times as short as 1 second there was a $60 \%$ uptake of the $0.2 \mathrm{mg} / \mathrm{l}$ pine barkt From the column studies it was shown that small amounts of $\mathrm{Ni}$ can be reduced also at even lower concentrationst $(<10 \mu \mathrm{g} / \mathrm{l})$. Contact time appeared to be especially important for Ni uptake to pine bark and it is likely to believe that an even higher contact time would result in a higher uptake of $\mathrm{Ni}$ to pine bark. The results for pine bark is in contrary to what was found for $\mathrm{Cu}$, $\mathrm{Zn}$ and $\mathrm{Pb}$ in previous study [17] which concluded that high removal efficiency was achieved even at short contact times and high metal concentrations for pine bark.

\section{CONCLUSIONS}

In the comparison between the filter materials on site, pine bark appeared to be not only the most effective but also the most stable sorbent for uptake of $\mathrm{Cu}, \mathrm{Zn}$ and $\mathrm{Ni}$.

$\mathrm{Zn}$ is the metal that in the on-site column study was removed to the highest extent at the lower flow rate. $\mathrm{Ni}$ on the other hand was sorbed to a lower extend. The capacity to remove Ni was however established in the laboratory experiment.

There is a series of parameters involved in the sorption process that in one way or another affects the metal removal efficiency. The relationship or importance of these has not yet been determined by research and there are still questions to answer. Further research requires a 
good overview of the knowledge to find experimental design to connect all these factors. Contact time is a very important parameter in reactive filter technology. For slag longer contact time is more important at low inlet concentrations whilst for pine bark a longer contact time is required if higher concentrations are to be reduced. Initial concentration of metals was important for the metal reduction rate. The relationship between initial concentration and uptake differs between different metals. The variations in $\mathrm{pH}$ can also be important, according to literature, and perhaps the choice of filter materials and design should take also this parameter into accountt

\section{ACKNOWLEDGEMENTS}

This study has been supported and financed by Mälarenergi, Eskilstuna Energi och Miljö and Vafab Miljö. The author would sincerely like to thank Ann-Sofie Magnusson and Christina Ingwall Johansson for unvaluable help in the laboratory. A part from this Gert Bard and cooperators at Eskilstuna Energi och Miljö is thanked for help with the experimental set up at Lilla Nyby landfill. The members of the VAFIM reference group are acknowledged for their interest and input to the project.

\section{REFERENCES}

[1] Öman, C., Malmberg, M., Wolf-Watz, C., 2000b. Utveckling av metoder för Karakterisering av lakvatten från avfallsupplag - Slutrapport. RVF Rapport nr: 3 (in Swedish).

[2] Suna Erses, A., Fazal, A. M., Onay, T. T., Craig, W. H., 2005. Determination of solid waste sorption capacity for selected heavy metals in landfills. Journal of Hazardous Materials B121, 223-232.

[3] Johansson, L., 1998. Phosphorus Sorption to Filter Substrates -Potential benefits for On-site Wastewater Treatment. Dissertation. Div. of Land and Water Resources, Royal Institute of Technology, Stockholm, Sweden.

[4] Edgehill, R.U., Lu, G.Q., 1998. Adsorption Characteristics of carbonized Bark for Phenol and Pentachlorophenol. J. Chem. Tech. Biotechnol 1998:71, 27-34.

[5] Freer, J., Baeza, J., Maturana, H., Palma, G., 1989. Removal and Recovery of uranium by Modified Pinus Radata D. Don Bark. Journal of Chemical Tech. Biotechnology 46, 41-48.

[6] Dimitrova, S. V., Mehandgiev, D. R., 1998. Lead removal from aqueous solution by granulated blast- furnace slag. Water Research 32(11), 3289.3292.

[7] Dimitrova, S. V., Mehandgiev, D. R., 1999. Interactions of blast-furnace slag with heavy metal ions in water solutions. Water Research 34(6), 1957-1961

[8] Dimitrova, S. V., 2002. Use of granular slag columns for lead removal. Water Research 36, 4001-4008.

[9] Gloaguen, V., Morvan, H., 1997. Removal of Heavy metal ions from aqueous solution by modified barks. J. Environ. Sci. Health A32(4), 901-912.

[10] Gustafsson, J-P., Jacks, G., Simonsson, M., Nilsson, I., 2004. Soil Water and Chemistry. Department of Land and Water Resources Engineering, KTH, Stockholm, Sweden.

[11] Nehrenheim, E., Johansson, Westholm, L., Waara, S., 2005. Treatment of landfill leachate using filter substrates. In: Proceedings of Sardinia '05, the $10^{\text {th }}$ International Waste and Landfill Symposium, Sardinia, Italy. 
[12] Nehrenheim, E., 2005. Sorption capacity to pine bark and blast furnace slag at various contact times, Manuscript in preparation.

[13] Homepage of Zugol, www.zugol.se, 2005-09-26.

[14] SS 028152, Water analysis - Atomic adsorption spectrometry, atomization in flame Special guidelines for aluminium, lead, iron, cadmium, cobalt, copper, chromium, manganese, nickel and zink (in Swedish).

[15] Shütte, K., 2005. Filtermaterial för lakvattenbehandling, erfarenheter från Lilla Nyby, Eskilstuna. Diploma Work at department of Public Technology, Mälardalen University (in Swedish).

[16] Öman, C., Malmberg, M. Wolf--Watz, C., 2000a. Handbok för Lakvattenbedömningtmetodik för karakterisering av lakvatten från avfallsupplag. RVF Rapport 00t7 (in Swedish).

[17] Färm, C., 2003. Constructed Filters and Detention Ponds for Metal Reduction in Storm Water. Doctoral Dissertation, Department of Public Technology, Mälardalen University.

[18] Shukla, S. S., Yu, L. J., Dorris, K. L., Shukla, A., 2004. Removal of nickel from aqueous solution by sawdust. Journal of hazardous materials B121, 243-246. 